Jpn. J. Med. Sci. Biol., 49, 69 - 74, 1996.

Short Communication

\title{
SEROEPIDEMIOLOGICAL SURVEY OF WILD RATS FOR SEOUL VIRUS IN INDONESIA
}

Ima-Nurisa IBRAHIM, Mohammad SUDOMO, Chiharu MORITA1*, Sachiko UEMURA1, Yasukazu MURAMATSU1, Hiroshi UENO1 and Takashi KITAMURA2

Health Ecology Research Center, National Institute of Health Research and Development, JI. Percetakan Negara No. 29, Jakarta 10560, Indonesia, 1 Department of Veterinary Public Health, Rakuno-Gakuen University, Bunkyodai-Midori-machi, Ebetsu-shi, Hokkaido 069, and 2Toyama Institute of Health, 17-1 Nakataikoyama, Kosugi-machi, Imizu-gun, Toyama 939-03

(Received February 13, 1996. Accepted April 2, 1996)

SUMMARY: The prevalence of antibodies against Seoul virus was investigated in 655 wild rats (Rattus norvegicus, $R$. rattus, $R$. rattus diardii, $R$. exulans, $R$. tiomanicus) captured in seven port areas of Indonesia. Twenty-four of $238 R$. norvegicus, one of $142 R$. rattus and one of $102 R$. exulans from two port areas had the antibodies against Seoul virus.

Seoul virus is a member of Genus Hantavirus of family Bunyaviridae and is an well-known zoonotic agent. The virus has spread throughout the world with the spread of the reservoir of the virus, Rattus norvegicus (1). In Southeast Asian countries, antibodies have been reported to be found in wild rats including

森田千春·上村幸子·村松康和·上野弘志(酪農学園大学獣医学部獣医公衆衛生学教室 江別市文京台緑町582)

北村＼cjkstart敬(富山県衛生研究所 富山県射水郡小杉町中太閤山17-1)

*Corresponding author. 


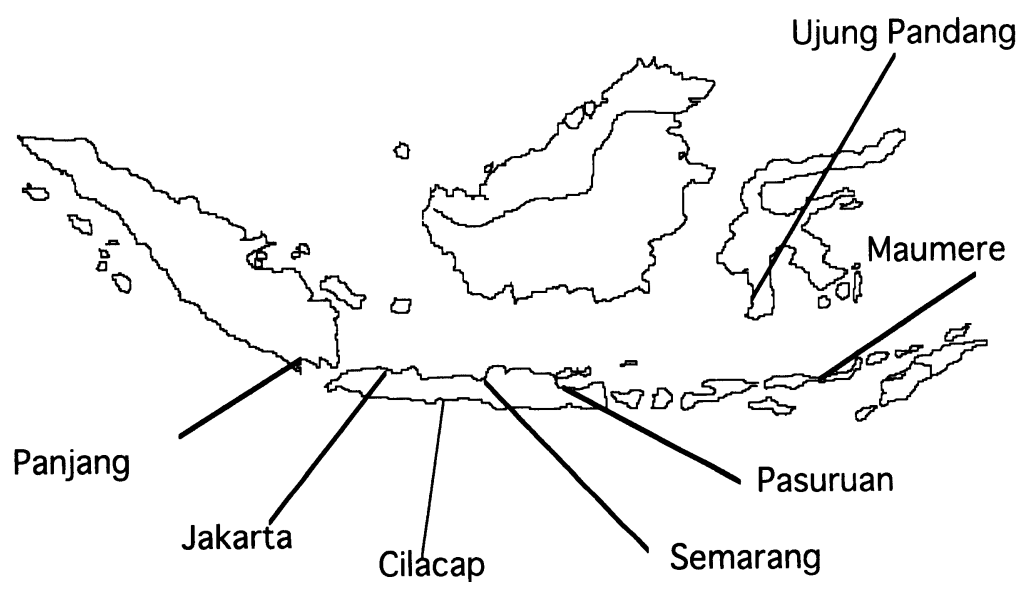

Fig. 1. Seven ports investigated in Indonesia

Bandicota spp. from Rangoon, Hong Kong, Manila, Thailand and Taiwan (1). Hemorrhagic fever with renal syndrome (HFRS) in humans was reported in Sri Lanka (2) and Singapore (3). In Indonesia, Ristiyanto et al. (4) reported that 7.9$11.7 \%$ of Rattus rattus from Maumere on the island of Flores had the antibody against Hantaan virus; however, the prevalence of the antibody in wild rats of other islands were not investigated. The present study attempted to clarify the prevalence of the antibody against Seoul virus in rats from several port areas on four islands of Indonesia.

Wild rat sera were collected from seven port areas on four islands of Indonesia from 1985 to 1992 (Fig. 1). The captured rats were divided into two groups, adult and juvenile, according to the body mass. In the case of $R$. norvegicus, when the body weight was less than $150 \mathrm{~g}$, it was regarded as a juvenile rat. The captured animals were anesthetized and blood was collected by using blood sampling filter paper (Toyo-Roshi, Tokyo), onto which $100 \mu$ l of blood was absorbed. After drying, the blood was eluted with $0.6 \mathrm{ml}$ of phosphate-buffered saline. The eluted serum was considered as a 16 -fold dilution.

Antibodies against Seoul virus were investigated by the indirect immunofluorescent antibody (IFA) method and positive sera in the IFA test were confirmed by the immune adherent hemagglutination (IAHA) test (5). The antigens for the tests were prepared from Vero-E6 cells infected with the SR-11 strain of Seoul virus. When the antibody titer was higher than 1:16 in the IFA and IAHA tests, the serum was considered to be positive. 
As shown in Table I, antibody-positive samples were found in two of the seven investigated areas (Ujung Pandang and Semarang). In Ujung Pandang, 24 of $164 R$. norvegicus (Range 1:16: - 1:16,384 Mode 1:256 in IFA) and one of four $R$. exulans (1:128 in IFA) had antibodies against Seoul virus. In Semarang, only one of $81 R$. rattus (1:512 in IFA) had the antibody against Seoul virus, while none of $39 R$. norvegicus had the antibody. None of $35 R$. norvegicus from the other five ports was seropositive against Seoul virus. None of $50 R$. rattus from Maumere had the antibody.

In $R$. norvegicus captured in 1985 from harbor areas and village areas of Ujung Pandang, there was significant difference $\left(\mathrm{P}<0.05, \mathrm{X}^{2}\right.$ test) in prevalence rate of the antibody between adult rats and juvenile rats, although no significant difference was observed in the prevalence rate of the antibody, either, between male and female rats (Table II). There was no significant difference between the prevalence rate of the antibody in rats in rainy season (April- October) and that in

Table I. Prevalence of the antibody to Seoul virus in wild rats in Indonesia

\begin{tabular}{|c|c|c|c|c|c|c|c|c|}
\hline \multirow{2}{*}{$\begin{array}{l}\text { Species } \\
\text { of } \\
\text { ratsb) }\end{array}$} & \multicolumn{7}{|c|}{ Areaa) } & \multirow{2}{*}{ Total } \\
\hline & UJP & SM & PSR & $\mathrm{AM}$ & KKPP & $\mathrm{KKCP}$ & BLK & \\
\hline $\begin{array}{l}\text { R.n. } \\
(\%)\end{array}$ & $\begin{array}{l}24 / 164 \mathrm{c}) \\
(14.6)\end{array}$ & $0 / 39$ & $0 / 32$ & $0 / 1$ & $0 / 0$ & $0 / 0$ & $0 / 2$ & $\begin{array}{l}24 / 238 \\
(10.1)\end{array}$ \\
\hline $\begin{array}{l}\text { R.r. } \\
(\%)\end{array}$ & $0 / 10$ & $\begin{array}{l}1 / 81 \\
(1.2)\end{array}$ & $0 / 0$ & $0 / 50$ & $0 / 0$ & $0 / 0$ & $0 / 1$ & $\begin{array}{l}1 / 142 \\
(0.7)\end{array}$ \\
\hline $\begin{array}{l}\text { R.r.d. } \\
(\%)\end{array}$ & $0 / 14$ & $0 / 0$ & $0 / 11$ & $0 / 0$ & $0 / 96$ & $0 / 35$ & $0 / 14$ & $0 / 170$ \\
\hline $\begin{array}{l}\text { R.e. } \\
(\%)\end{array}$ & $\begin{array}{l}1 / 4 \\
(25.0)\end{array}$ & $0 / 91$ & $0 / 7$ & $0 / 0$ & $0 / 0$ & $0 / 0$ & $0 / 0$ & $\begin{array}{l}1 / 102 \\
(1.0)\end{array}$ \\
\hline $\begin{array}{l}\text { R.t. } \\
(\%)\end{array}$ & $0 / 2$ & $0 / 1$ & $0 / 0$ & $0 / 0$ & $0 / 0$ & $0 / 0$ & $0 / 0$ & $0 / 3$ \\
\hline $\begin{array}{l}\text { Total } \\
\text { (\%) }\end{array}$ & $\begin{array}{l}25 / 194 \\
(12.9)\end{array}$ & $\begin{array}{l}1 / 212 \\
(0.5)\end{array}$ & $0 / 50$ & $0 / 51$ & $0 / 96$ & $0 / 35$ & $0 / 17$ & $\begin{array}{l}26 / 655 \\
(4.0)\end{array}$ \\
\hline
\end{tabular}

a)UJP: Ujung Pandang, SM: Semarang, PSR: Pasuruan, AM: Maumere, KKPP: Panjang, KKPC: Cilacap, BLK: Jakarta. b)R.n.: Rattus norvegicus, R.r.: Rattus rattus, R.r.d.: Rattus rattus diardii, R.e.: Rattus exulans, R.t.: Rattus tiomanicus. c)number of positive/number of tested. 
dry season (November-March). Significant difference was not found in the prevalence rate of the antibody between rats from harbor areas and those from the village areas (Table III).

Indonesia comprises over 13,000 islands with 46 major ports. In the present study, seven ports (four on the island of Java, one on the island of Sumatra, one on the island of Flores and one on the island of Sulawesi) were investigated for the prevalence of the antibody against Seoul virus in wild rats. Most of positive samples were obtained from $R$. norvegicus in Ujung Pandang on the island of Sulawesi. Two positive samples were found in $R$. exulans from Ujung Pandang and in $R$. rattus from Semarang on the island of Java. The role of the two species in the spread of the virus is unknown. Although antibodies against Hantaan virus were reported in $R$. rattus in Maumere (4), no seropositive sample was found

Table II. Prevalence of antibody to Seoul virus in Rattus norvegicus in Ujung Pandang by age and sex

\begin{tabular}{llll}
\hline Sex & Adult & Juvenile & Total \\
\hline Male & $7 / 58 \mathrm{a})(12.1 \%)$ & $0 / 4(0 \%)$ & $7 / 62(11.3 \%)$ \\
Female & $17 / 85(20.0 \%)$ & $0 / 17(0 \%)$ & $17 / 102(16.7 \%)$ \\
Total & $24 / 143(16.8 \%)$ & $0 / 21(0 \%)$ & $24 / 164(14.6)$ \\
\hline
\end{tabular}

a) number of positives / number of tested.

Table III. Prevalence of antibody to Seoul virus in Rattus norvegicus in Ujung Pandang by season and habitat

\begin{tabular}{llll}
\hline Season & Harbor & Village & Total \\
\hline Rainy & $4 / 25 \mathrm{a})(16.0 \%)$ & $2 / 14(14.3 \%)$ & $6 / 39(15.38 \%)$ \\
Dry & $6 / 56(10.7)$ & $13 / 69(17.4 \%)$ & $18 / 125(14.4 \%)$ \\
Total & $10 / 81(12.3 \%)$ & $14 / 83(16.9 \%)$ & $24 / 164(14.6 \%)$ \\
\hline
\end{tabular}

a) number of positives / number of tested. 
from wild rats in this study. It was difficult to explain this discrepancy. However, it could have been due to the methods for detection of antibody, because false positive reaction could not be excluded by a single seroexamination method. In $R$. norvegicus, transmission of the virus occurred more frequently in adult rats than in juvenile ones. The same mode of transmission of the virus in rats has been reported in other countries $(6,7)$. $R$. norvegicus is thought to be the most important reservoir of Seoul virus in Indonesia as well as in other countries. The infection of the virus has spread into the village area in Ujung Pandang, indicataing that the invasion of the virus into Ujung Pandang had occurred before 1985. Similar findings were reported in Tokyo, Japan in 1960's (8). As the antibody has been found in wild rats from several ports in Indonesia, careful surveillance of the virus in wild rats as well as in humans should be continued in Indonesia.

\section{ACKNOWLEDGEMENTS}

The authors wish to express their sincere thanks to Dr. Tuti R. Hadi, Health Ecology Research Centre, National Institute of Health Research and Development, for her invaluable efforts in the collection of samples; we dedicate this report to her following her untimely death.

\section{REFERENCES}

1. LeDuc, J. W., Smith, G. A., Childs, J. E., Pinheiro, F. P., Maiztegui, J. I., Niklasson, B., Antoniades, A., Robinson, D. M., Khin, M., Shortridge, K. F., Wooster, M. T., Elwell, M. R., Ilbery, P. L. T., Koech, D., Rosa, E. S. T. and Rosen, L. (1986): Global survey of antibody to Hantaan-related virus among perdomestic rodents. Bull. W. H. 0., 64, 139-144.

2. Vitarana, T., Colombage, G., Bandaranayake, V. and Lee, H. W. (1988): Hantavirus disease in Sri Lanka. Lancet, ii, 1263.

3. Wong, T. W., Chan, Y. C., Joo, Y. G., Lee, H. W., Lee, P. W. and Yanagihara, R. (1989): Hantavirus infection in humans and commensal rodents in Singapore. Trans. R. Soc. Trop. Med. Hyg., 83, 248-251.

4. Ristiyanto, Hadi, T. R. and Man, H. (1994): A survey on rats and ectoparasites and their role in transmission of Hantaan virus in Maumere, Flores. Maj. Parasitol. Ind., 7, 45-52 (in Indonesian).

5. Sugiyama, K., Matsuura, Y., Morita, C., Morikawa, S., Komatsu, T., Shiga, S., Akao, Y. and Kitamura, T. (1984): An immune adherence assay for dis- 
crimination between etiologic agent of hemorrhagic fever with renal syndrome. J. Infect. Dis., 149, 67-73.

6. Childs, J. E., Korch, G. W., Smith, G. A., Terry, A. D. and LeDuc, J. W. (1985): Geographical distribution and age related prevalence of antibody to Hantaan-like virus in rat populations of Baltimore, Maryland, U.S.A. Am. J. Trop. Med. Hyg., 34, 385-387.

7. Sugiyama, K., Minaba, K., Morita, C., Kitamura, H., Yamada, T., Ogura, K., Tanaka, R., Tanikawa, T., Shiga, S., Komatsu, T. and Kitamura, T. (1993): Epizootiological study of Hantavirus infection among Rattus norvegicus in Tokyo Bay area, Japan. Jpn. J. Med. Sci. Biol., 46, 75-86.

8. Morita, C., Takeuchi, Y., Matsuura, Y. and Kitamura, T. (1989): The prevalence of Hantaan viruses among Rattus norvegicus in Tokyo in the 1960's. J. Vet. Med., B 36, 557-558. 